Available online at: http://ejournal-balitbang.kkp.go.id/index.php/ifrj
e-mail:ifrj.puslitbangkan@ gmail.com
INDONESIAN FISHERIES RESEARCH JOURNAL
Volume 22 Number 1 June 2016
p-ISSN: 0853-8980
e-ISSN: 2502-6569
Accreditation Number: 704/AU3/P2MI-LIPI/10/2015

\title{
BIOLOGY AND CPUE SPATIAL DISTRIBUTION OF ESCOLAR Lepidocybium flavobrunneum (Smith, 1843) IN EASTERN INDIAN OCEAN (EVOLVING FISHERIES: TODAY'S BY-CATCH IS TOMORROW'S TARGET CATCH)
}

\author{
Fathur Rochman*1, Irwan Jatmiko and Arief Wujdi ${ }^{1}$ \\ ${ }^{1}$ Research Institute for Tuna Fisheries, Mertasari Road, No. $140 \mathrm{Br}$. Suwung Kangin, Desa Sidakarya, Denpasar Selatan, \\ Denpasar-Bali, Indonesia 80224 \\ Correspondence: fathursmasabio1@gmail.com \\ Received; January 29-2015 Received in revised from April 25-2016; Accepted May 03-2016
}

\begin{abstract}
Discharge of by catch is a significant problem in world fishery. Every commercial fishery such as tuna longline has a suite of bycatch species, escolar fish (LEC). LEC as by catch product has received a little attention because of its lower economic value and given its importance as a secondary market. With time, however, market can become establish for this presently undesirable species. Acknowledging that today's by catch might become tomorrow's target fish. The aims of this study are to provide information on biological aspect and catch per unit of effort (CPUE) spatial distribution of escolar (Lepidocybium flavobrunneum) as by catch in Indonesian longline fishery operating in the Eastern Indian Ocean. Total escolar samples of 1,815 were taken from scientific observer data from 2011-2013. The study area of escolar was between $0.897-33.175^{\circ} \mathrm{S}$ and $85.366-$ $138.733^{\circ} \mathrm{E}$ of Eastern Indian Ocean. Results show that the escolar length (cmFL) is distributed from 27-178 cmFL (median=83 cmFL, mode=85 cmFL, mean=83.95 cmFL and $\mathrm{n}=1.812$ ) and dominated by the size of $85 \mathrm{cmFL}$. The length weight relationship was determined to be $\mathrm{W}=0.0002 \mathrm{FL}^{2.2926}(\mathrm{~W}$ in $\mathrm{kg}, \mathrm{FL}$ in $\mathrm{cm})$. In terms of CPUEs distribution, the lower CPUEs $(<1.0001)$ generally occurred near shore between Indonesia and Australia (10-20 $\mathrm{S}$ and $\left.110-125^{\circ} \mathrm{E}\right)$. The highest CPUEs of escolar (>1.0001 to 7.382) generally occurred in Western Australian, precisely on grid between $10-35^{\circ} \mathrm{S}$ and $85-110^{\circ} \mathrm{E}$. These grids would be a potential for fishing LEC with the best time to catch in June to August.
\end{abstract}

\section{Keyword: Tuna Longline; bycatch; escolar; CPUE; Indian Ocean}

\section{INTRODUCTION}

Indonesian longline fisheries are based upon the economics value. The establishment of commercial fisheries, there has been only one "universal law" that supersedes all others when it comes to economic market: the law of supply and demand. The direction of all commercial fisheries depends on this common law. Historically, commercial fisheries market has evolved or emerges to balance this fundamental law (Levesque, 2010).

Two of the greatest challenges in fisheries management are controlled by the catch and understanding emerging fishery markets. Discharge of by catch is a significant problem in world fishery. Every commercial fishery has a suite of by catch species that is discharged (dead or alive) at sea because they have a little to no economic value. With time, however, market can become establish for some of these presently undesirable species. Acknowledging that today's by catch might be tomorrow's target fish (Levesque, 2010).

The example of by catch species that has received little research attention because of its lower economic value is the escolar (Lepidocybium flavobrunneum). At one time escolar was worthless by catch of tuna pelagic longline fisheries. Today, escolar still do not support a directed fishery, but this species now landed, marketed and sold for profit (Graves, 1998).

LEC is a common bycatch in pelagic longline fisheries with targeting tuna and swordfish. According to Nakamura \& Parin (1993), escolar is a member of the Gempylidae family. This fish is widely distributed 
in tropical and subtropical (sometimes temperate) waters of the eastern Indian Ocean, the Western Pacific and the Western Central Atlantic. The fish is known as meso or bathypelagic species and mostly over the continental slope, down to $200 \mathrm{~m}$ and more. Often migrates upward at night (Riede, 2004). Feeds on squid, fishes (bramids, coryphaenids, scombrids, trachipterids, etc.) and crustaceans, this species inhabits along the continental edge of the continental shelf and upper slope (Shcherbachev, 1987).

Relative to the oilfish (Ruvettus pretiosus), LEC cannot metabolize the wax esters (gempylotoxin) which is naturally found in its diet. This gives the LEC an oil content of $14-25 \%$ in its flesh/body. LEC contains strong purgative oil, that when consumed can cause diarrhea known as Gempylid Fish Poisoning or Gempylotoxism (Roche et al., 2002; Feldman et al., 2005). Despite its relative commercial important, little has been documented about LEC catch characteristics in commercial fisheries. This paper aims to provide information on fishing characteristics, relative abundance, distribution and size composition of the LEC catch in the Indian Ocean based at Benoa-Bali. The overarching goal is to emphasize the importance of evaluating, managing and conserving lower-valued species.

\section{MATERIALS AND METHODS Escolar Fish Description}

LEC (Fig.1) is known as black oilfish or snake mackerel. In the market, this fish fraudulently marketed as butterfish, walu/waloo and white tuna. Fisherman in Indonesia called as "ikan setan coklat abu-abu". Nakamura \& Parin (1993) described the short description of escolar as follows; escolar has a fusiform body, with four to six finlets behind the second dorsal and anal fins. It has a strong keel on the side of the caudal peduncle, which is flanked by a smaller keel above and below. Its upper jaw has two pairs of fangs anteriorly. The species is dark brown becoming almost black as it ages. This fish can grow over two meter length.

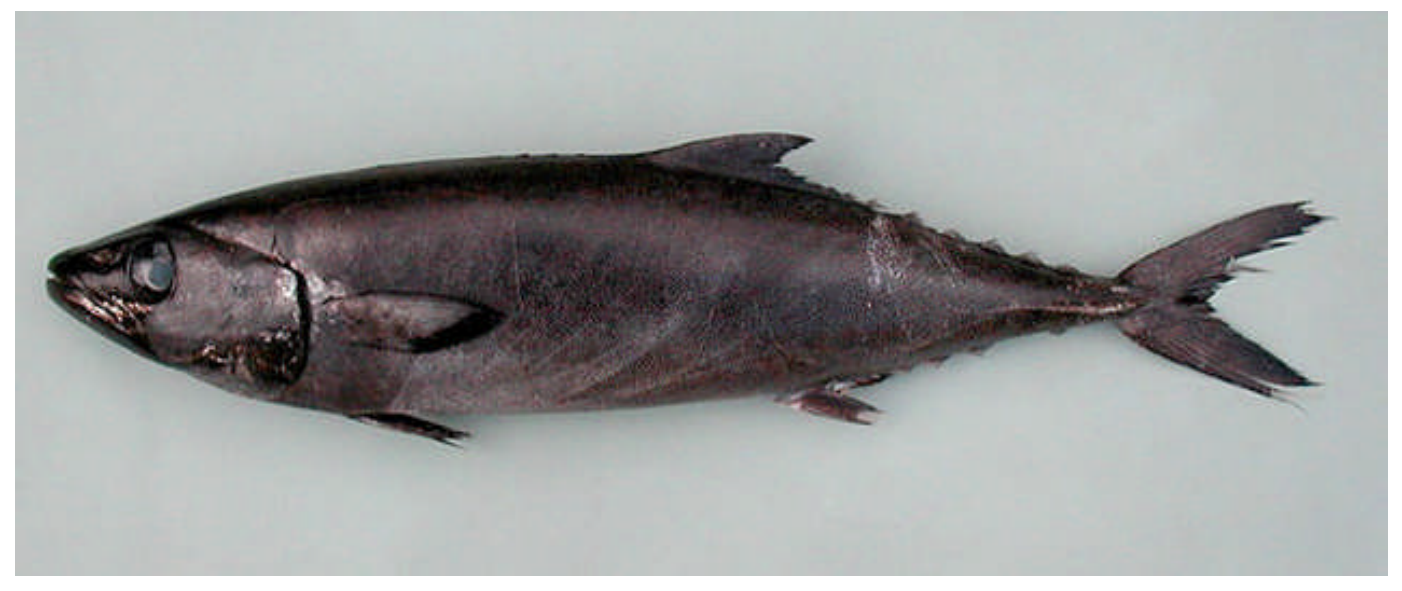

Figure 1. Escolar fish (Lepidocybium flavobrunneum) (Smith, 1843) with $77 \mathrm{cmTL}$. Source : Fish Base FAO, Brazil by (Vaske Jr. Teodoro) (Lefla_u2.jpg).

\section{Study Area}

The escolar fishing ground caught by tuna longline fisheries extends from $\left(0.897-33.175^{\circ} \mathrm{S}\right.$ and 85.366 $\left.-138.733^{\circ} \mathrm{E}\right)$ of Eastern Indian Ocean. The escolar fishing ground is following tuna long line effort and mostly conducted outside Indonesian Exclusive Economic Zone (EEZ) as presented in Figure 2. 


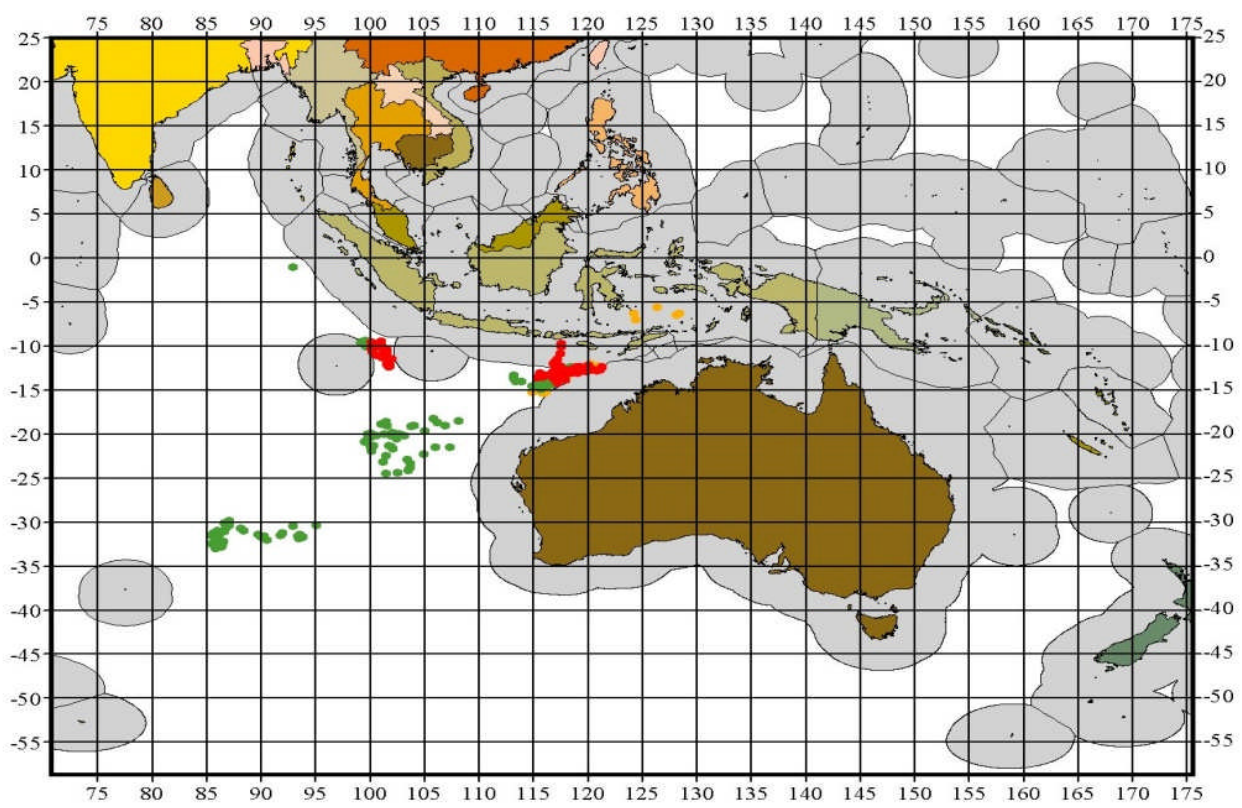

Figure 2. Fishing ground position of LEC caught by tuna long line during onboard observer program (20112013) which also describes the potential of horizontal distribution of LEC.

Catch data of LEC included CPUEs were georeferenced in $5^{\circ}$ grids of latitudes and longitudes. A surfer9 program was used to describe the spatial distribution of CPUE.

\section{Data Gathering and Analysis}

Data were gathered from onboard observer program on commercial tuna longline fleets based at BenoaBali in the period March 2011to October 2013. The observer program is collaboration between Indonesia's Ministry of Marine Affairs and Fisheries (MMAF) through the Research Centre for Capture Fisheries (RCCF) or now Centre for Fisheries Research and Development, and CSIRO Marine and Atmospheric Research (Australia), and is funded by Australian Centre for International Agricultural Research (ACIAR). This program was designed to produce accurate catch and effort data from Indonesia's Indian Ocean industrial tuna longline fishery based at Benoa, and also to provide detailed information in terms of fishing activities and environmental condition. Since 2011, the Scientific Observer Program has been undertaken by Research Institute for Tuna Fisheries (RITF).

Fisheries observer recorded fishing characteristic (e.g., number of hooks, float and depth), catch (species, size, and sex), status of catch (unknown, alive, dead, or damage), and action of catch (unknown, release alive/dead, kept, finned, lost, or tended). Identification of fish species refer to Collette \& Nauen
(1983), Sainsbury et al. (1985) and Sommer et al. (1996).

The fishing effort (f) and CPUEs for LEC was calculated using the following formula, modified from De Metrio \& Megalofonou (1998):

$$
f=\left(a^{\prime} / 1000\right) \times d
$$

Where $a^{\prime}$ is the average number of hooks in longline per day (divided by the 1000 hooks longline effort unit), and $d^{\prime}$ is the number of fishing days per trip. $C P U E=N / f \quad$ ( $N$ is the number of fish caught) $\mathrm{CPUE}=\mathrm{B} / \mathrm{f}$ ( $\mathrm{B}$ is the biomass of fish caught)

The equation to recognized Catch per Unit Effort (CPUE) was using the equation of Gunarso \& Wiyono (1994) as follows:

$$
\text { CPUE }_{i}=\text { Catch }_{\text {Effort }_{i}}
$$

where,

Catch $_{i}\left(C_{i}\right)=$ catch result in year $-\mathrm{i}$ (ton)

Effort $\left(E_{i}\right)=$ catch effort in year $-i$ (unit)

CPUE = $\begin{gathered}\text { catch Per Unit of Effort in years } \mathrm{i} \text { (ton/ } \\ \text { unit) }\end{gathered}$

Prior to analysis, all datasets were tested for normality and homoscedacity using KolmogorovSmirnov test and Levene test. 


\section{RESULTS AND DISCUSSION}

\section{Results}

\section{Size Distribution}

Total LEC samples analyzed were 1.815 , taken from scientific observer data ranging from 2011-2013.
LEC length (cmFL)is distributed from $27-178 \mathrm{cmFL}$ (median $=83 \mathrm{cmFL}$, mode $=85 \mathrm{cmFL}$, mean $=83.95$ $\mathrm{cmFLand} \mathrm{n}=1.812$ ) and dominated at size $85 \mathrm{~cm}$. The data also identified male and female of LEC with the comparison 120 male and 1.065 female $(1: 8.8)$ (Fig. 3).
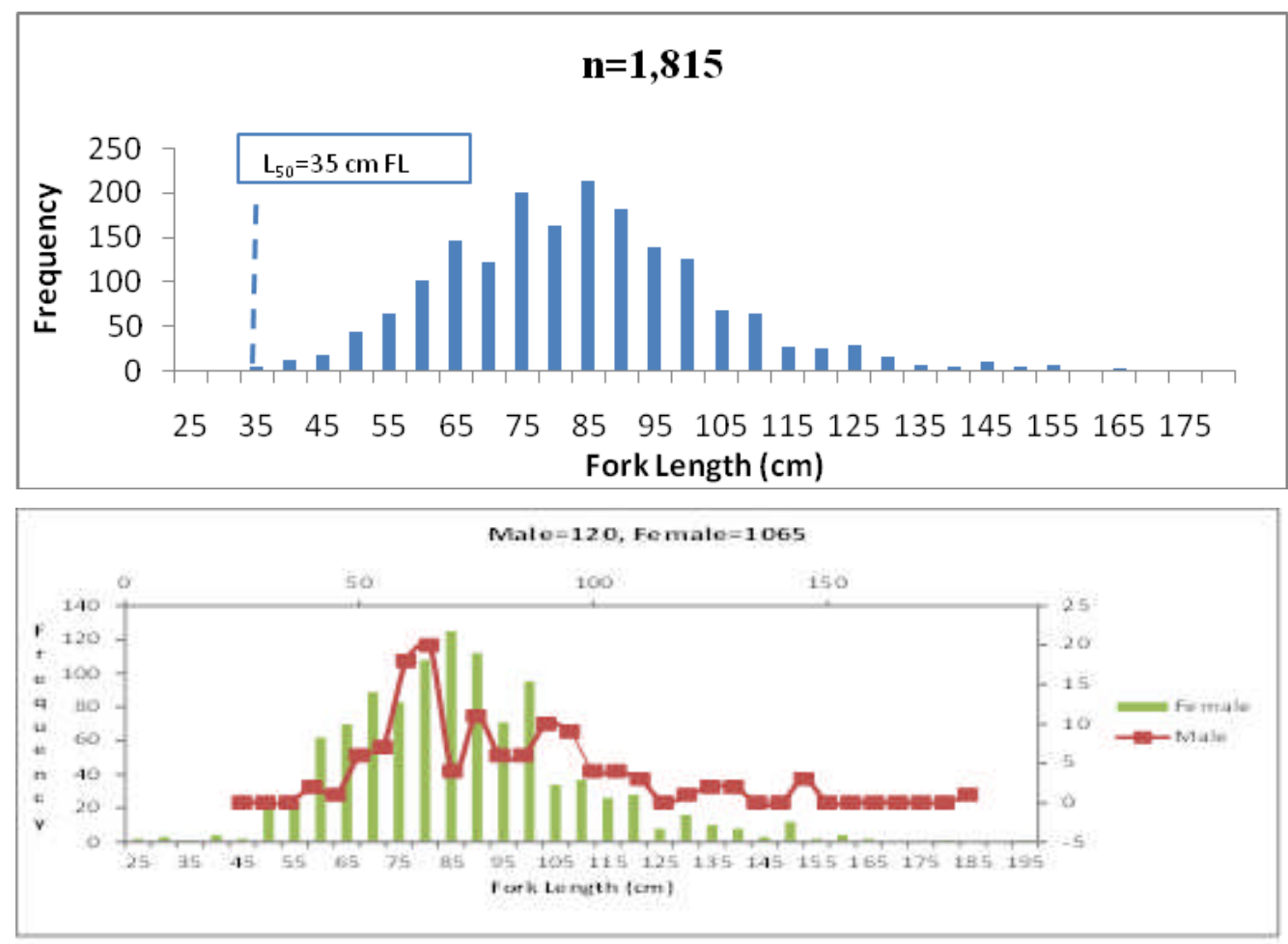

Figure 3. Length frequency distribution for LEC observed taken in Indonesian longline fishery operating in Eastern Indian Ocean in 2011-2013.Dash line is length of fish with probability to perform reproduction $\left(\mathrm{L}_{50}\right)$.

The data also consisted of mean fork length distribution by month and by year. Monthly mean fork length ranged from $63.88 \mathrm{cmFL}$ (November) to 93.49 cmFL (August) (Fig.4). Mean fork lengths by year were $74 \mathrm{cmFL}, 77 \mathrm{cmFLand} 85 \mathrm{cmFL}$ in 2011, 2013, and 2012, respectively. Mean length distribution of LEC showed significant different of each month (Anova,
$\mathrm{P}<0.001)$. Scheffe post-hoc multiple comparison test shows that the highest mean length distribution occurred in August (93.49 cmFL). Mean length distribution in August has significant different with June ( $83.51 \mathrm{cmFL})$ and July $(83.49 \mathrm{cmFL})$ but not significant difference with September $(84.39 \mathrm{cmFL})$.

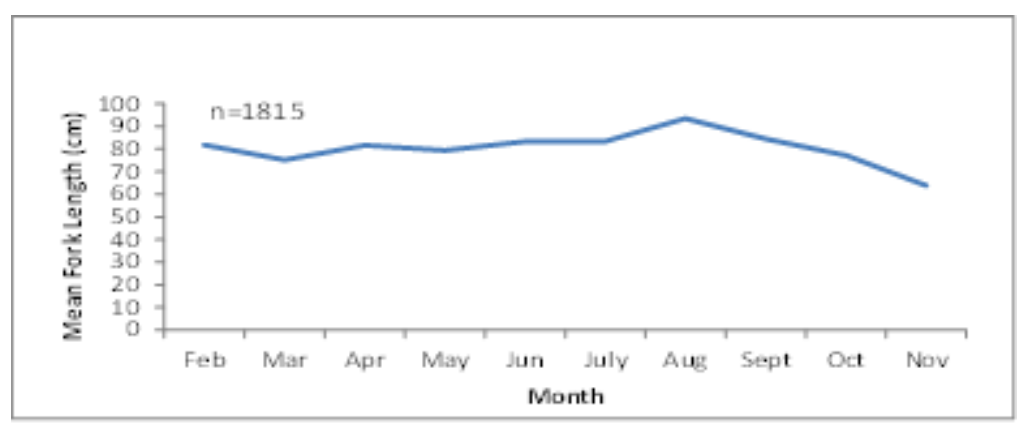

Figure 4. Mean fork length distribution by month for LEC observed taken in the Indonesian pelagic longline fishery operating in Eastern Indian Ocean (2011-2013). 


\section{Length and Weight Relationship}

The data were taken from observer program from 2011-2013, with 282 samples. The result of t-test showed the significant different with b value 2.2969
$(<3)$ and a value 0.0002 (Fig.5). It's assumed that growth pattern of LEC were negative allometric, where the growth in length is faster than the growth in weight. The comparison of length-weight of LEC in other oceans is shown in Table 1.
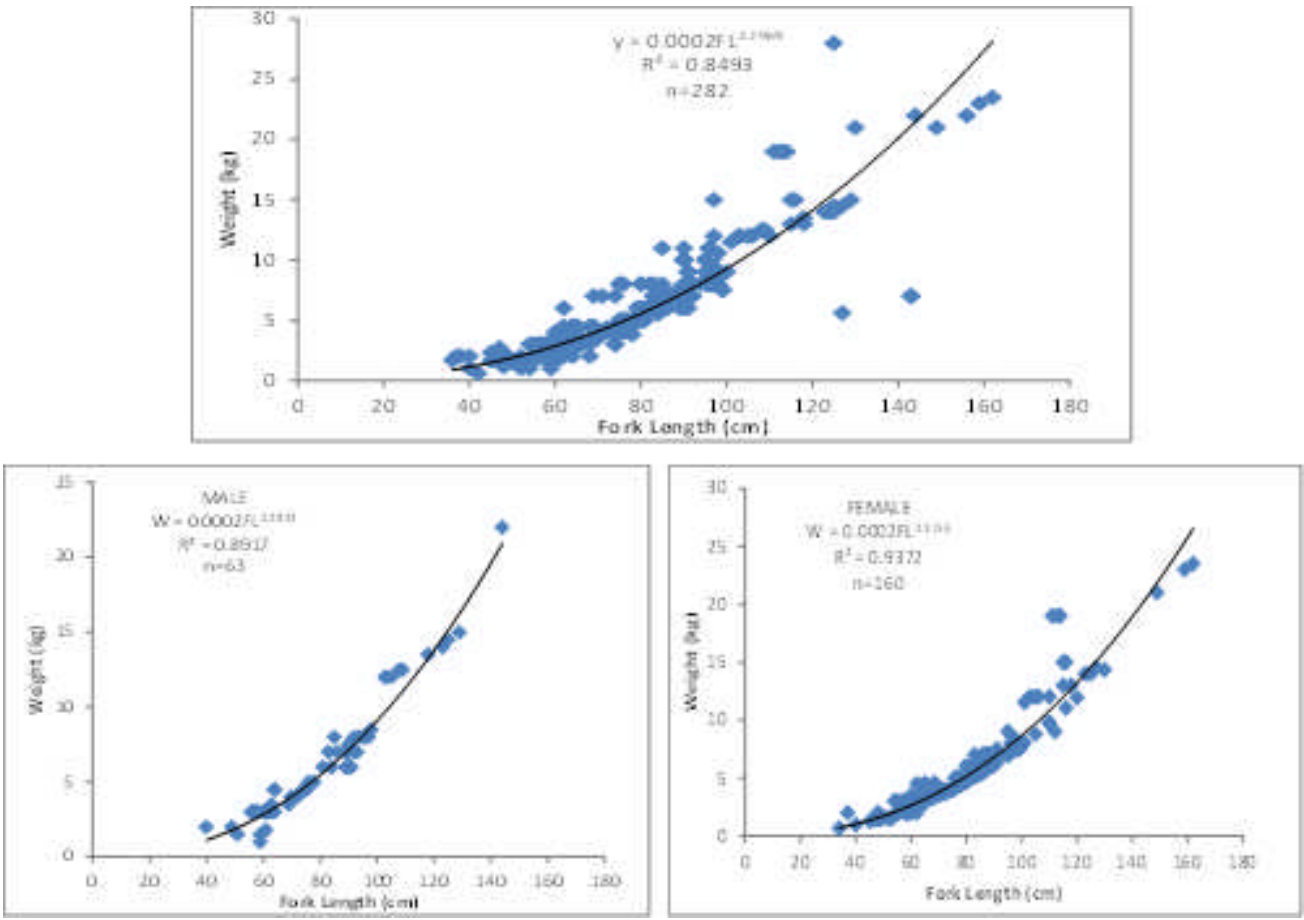

Figure 5. Weight-fork length fit exponential model of LEC sampled from the Indonesia's Scientific Observer operating in Eastern Indian Ocean in 2011-2013.

Table1. Length-weight relationship of LEC inother locations (compile from several authors)

\begin{tabular}{|c|c|c|c|c|c|c|c|}
\hline No & Author & Location & $\mathbf{n}$ & $\begin{array}{l}\text { FL Range } \\
\text { (cm) }\end{array}$ & $\begin{array}{l}\text { Intercept } \\
\text { (a) }\end{array}$ & $\begin{array}{l}\text { Slope } \\
\text { (b) }\end{array}$ & R2 \\
\hline 1 & Rochman et al. (2014) & $\begin{array}{l}\text { East Indian Ocean } \\
\text { Western North }\end{array}$ & 282 & $36-162$ & 0.0002 & 2.2969 & 0.84 \\
\hline 2 & $\begin{array}{l}\text { Levesque (2010) } \\
\text { Keller and Kerstetter }\end{array}$ & Atlantic & 44 & $18-182$ & 0.0003 & 2.3226 & 0.81 \\
\hline 3 & $\begin{array}{l}(2012) \\
\text { Lorenzo and }\end{array}$ & $\begin{array}{l}\text { Gulf of Mexico } \\
\text { Central East }\end{array}$ & 23 & $41-78$ & 0.0000044 & 3.152 & 0.95 \\
\hline 4 & Pajuelo(1995) & Atlantic & 776 & $36-80$ & 0.004521 & 2.98932 & 0.99 \\
\hline
\end{tabular}

\section{Catch Per Unit Effort (CPUE)}

The data of catch rate and catch per unit effort (CPUE) of LEC caught by tuna long line fleets are tabulated by year in Table 2 .
The overall moving average of CPUE showed that LEC catches generally increase from November to (June, July and August) and decrease in August to November (Fig. 6). 
Table 2. Catch Rate and Catch Per Unit Effort of escolar caught by tuna long line fleets based in Benoa during year 2011-2013.

\begin{tabular}{|c|c|c|c|c|c|c|c|c|c|}
\hline No & Year & $\sum_{\text {Effort }}$ & Number & $\begin{array}{c}\text { Cacth } \\
\text { Number } \\
\text { (pcs) }\end{array}$ & Tonnage & $\begin{array}{c}\text { Average } \\
\text { Weight }\end{array}$ & $\begin{array}{l}\text { (No. } \\
\text { fish/1000 } \\
\text { hooks }\end{array}$ & (Number/effort) & (kg/effort) \\
\hline 1 & 2011 & 132 & 134,414 & 103 & 455 & 4.42 & 0.766 & 0.78 & 3.45 \\
\hline 2 & 2012 & 193 & 280,935 & 1423 & 8466 & 5.95 & 5.065 & 7.37 & 43.87 \\
\hline 3 & 2013 & 224 & 227,607 & 286 & 1474 & 5.15 & 1.257 & 1.28 & 6.58 \\
\hline
\end{tabular}

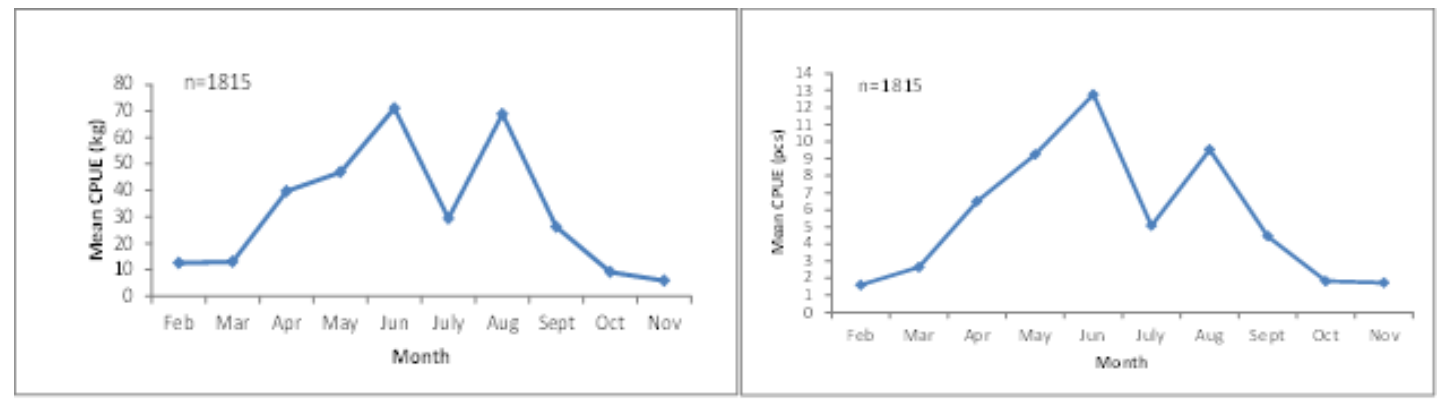

Figure 6. Mean Catch per Unit Effort (CPUE) of LEC by month in Eastern Indian Ocean (2011-2013).

From 18 tuna long line observer trips, all of trips caught LEC with total number of escolar were 1.882 fishes with CPUEs ranging between $0.766-5.065$ per 1.000 hooks (Table 2). From the extended study area, the coordinate of the study area was divided into $5 \times 5^{\circ}$ grid to recognize CPUE value. The spatial CPUEs distribution of LEC in Eastern Indian Ocean is shown in Figure 7.

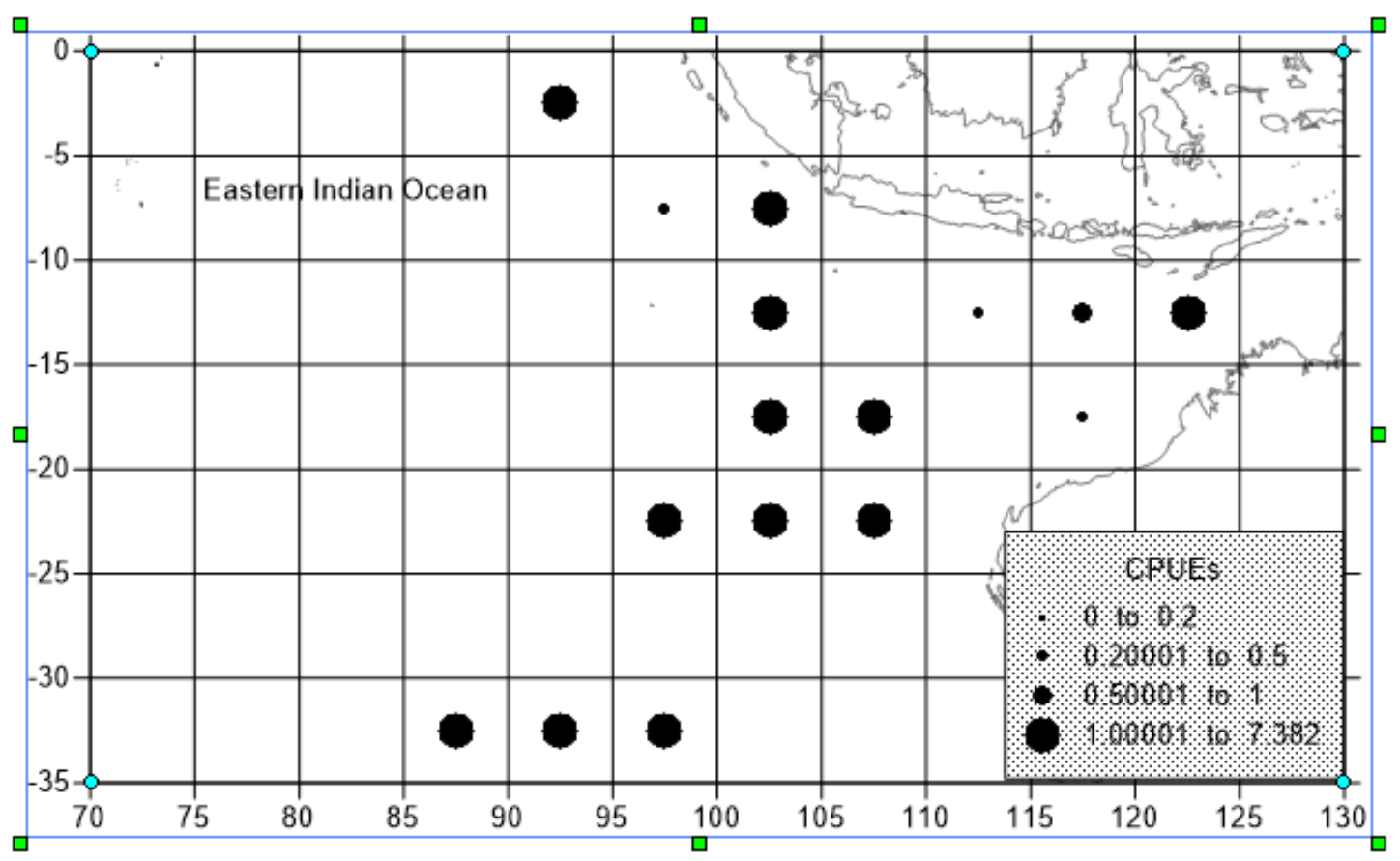

Figure 7. Spatial distribution of nominal CPUEs (no. of fish/1000 hooks) for LEC recorded by Benoa Observer, aggregated from 2010-2013 with $5 \times 5$ grids. 


\section{Discussion Size Distribution}

The overall mean size and length frequency distribution of LEC taken in the Eastern Indian Ocean (mean $=83.95 \mathrm{cmFL}$, min $=25 \mathrm{cmFL}$ and $\max =180$ $\mathrm{cmFL}$ ) was smaller to that of the Western Atlantic Ocean (89.5 cmFL) (Levesque, 2010) and Pacific Ocean (90 cmFL) (Nishikawa \& Warashina, 1998) but larger than those reported by (Lorenzo \& Pajuelo, 1999) in Canary Island Atlantic Ocean (max.78.90 $\mathrm{cmTL}$ ). The LEC are thought to reach maturity by 30 $35 \mathrm{cmFL}$ and larvae are predominantly found near islands, suggesting that spawning occurs in near-shore areas, adjacent to oceanic islands or continental landmasses (Maximov, 1970; Nishikawa,1982 in Brendtro et al., 2008). From the existing data, the female and male of LEC identified ranged from size $34 \mathrm{cmFL}$ to $178 \mathrm{cmFL}$ with the appearance of the egg and sperm. Refer to this information, it presumes that LEC caught by tuna longline fisheries in the Eastern Indian Ocean mostly would be adult.

Seasonal mean-length distributions were significantly different among month with the largest difference between November (mean $=63.88 \mathrm{cmFL}$ ) and August (mean $=93.49 \mathrm{cmFL}$ ). Overall, the data show that mean length of LEC increased from November to August with peak performance in August. It might be due to seasonal movement caused by reproductive behavior. Lorenzo \& Pajuelo (1995) reported that reproductive of roudi escolar extends from April to September, and peaks in June and July. The tested ovary were resting (stage II) during the period from November to March, mature gonad (stage III) appeared in April and increased in May and become dominant in June and July. The spawning male and female are dominant in June and July and also recorded in August and November.

Inter-annual mean length distribution was significantly different among years. The smallest $(74$ cmFL) LEC was taken in 2011 and the largest (85 $\mathrm{cmFL}$ ) in 2012. The difference of mean length distribution of LEC by year caused by the position of study area (fishing ground) in Eastern Indian Ocean. In 2011 and 2013, LEC were caught near oceanic island with coordinate ranging from $(9-15)^{\circ} \mathrm{S}$ to $(100-$ 128) ${ }^{\circ} \mathrm{E}$. In 2012 , LEC caught far from the oceanic island with coordinate range from (0-33) ${ }^{\circ} \mathrm{S}$ to (85$117)^{\circ} \mathrm{E}$. According to Nishikawa (1982), the larva of LEC were predominantly found near Island, suggesting that spawning occurs in near-shore areas, adjacent to oceanic islands or continental land masses.
The sex ratio of male to female LEC was significantly different than the expected $1: 1$. The sex ratio of male to female of LEC in Eastern Indian Ocean based on observer data 2011-2013 was (1:8.9). It is different with the Western North Atlantic Ocean that reported by Levesque (2010) which showed that sex ratio of male to female was 1:1.86. Lorenzo \& Pajuelo (1995) also reported that sex ratio of roudi escolar in Eastern North Atlantic was 1:1.96.

\section{Length and Weight Relationship}

Length-weight relationship of all LEC in this study was negative allometric, where the growth in length is faster than the growth in weight including male and female. Test of $b$ (slope) value of male was 2.2823 and female was 2.3155. The slope of male was slightly lower than female. Overall, the slope of lengthweight relationship of LEC in Eastern Indian Ocean was slightly lower compared with Levesque (2010) in Western North Atlantic, Keller \&Kerstetter (2012) in Gulf of Mexico and Lorenzo \& Pajuelo (1995) in Central East Atlantic. Complete comparisons are shown in Table 1.

\section{Catch Per Unit Effort (CPUE)}

The CPUEs distribution of LEC showed the uneven distribution. The highest CPUE (>1.0001 to 7.382) generally occurred in Western Australian, precisely on grid $10-35^{\circ} \mathrm{S}$ and $85-110^{\circ} \mathrm{E}$. The lower CPUEs $(<1.0001)$ generally occurred near shore Indonesia and Australia $\left(10-20^{\circ} \mathrm{S}\right.$ and $\left.110-125^{\circ} \mathrm{E}\right)$. According to Levesque (2010), the CPUE values caused by several factors such as reproductive behavior and feeding behavior. In the open-ocean environment, the availability of food is often limited to specific areas of oceanic convergence (currents, and sea mounts or ridge), which creates productive fishing conditions at certain times of year.

There is an evidence that seamounts form hotspots of biological activity in the oceans. Over large geographic scales ocean predators appear to be associated with seamounts and other features. Tuna, billfish, sharks, cetaceans, pinnipeds, turtles and seabirds may all be associated with seamounts, and high biomass and abundance of such predators have been observed in the vicinity of seamounts (Holland \& Grubs, 2007 in Rogers, 2012). Seamounts may also be associated with turbulent mixing caused by internal or baroclinic waves that can also induce upwelling of nutrients (Kunze \& Sanford, 1997; Toole 
et al.,1997 in Rogers., 2012). It is now recognized that several other physical processes associated with seamounts may enhance productivity or food supply in their vicinity. These include tidal rectification (generation of mean residual currents by tidal flow), flow acceleration and the formation of internal waves, and can enhance vertical mixing around a seamount, causing upwelling of nutrient-rich deep water and enhancement of primary production (White et al., 2007; Lavelle \& Mohn, 2010 in Rogers, 2012).

The CPUEs rate of LEC is allegedly associated with the presence of seamount and ridge in Indian Ocean. The coordinate with highest CPUEs of LEC is the area of seamount and ridge (Broken Ridge and Nineyeast Ridge) as shown in Figure 8.

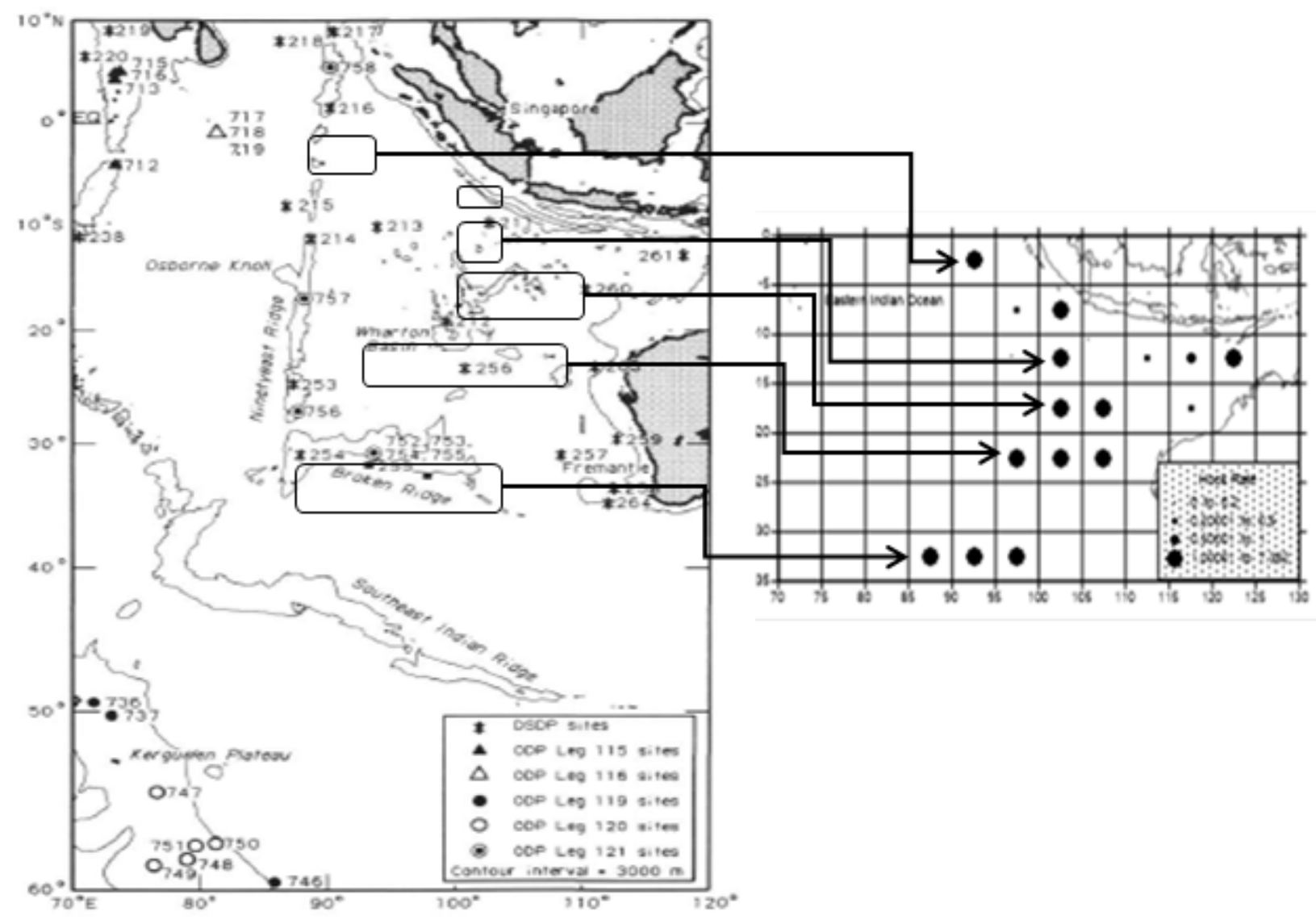

Figure 8. Bathymetric features of the Eastern Indian Ocean including location of Leg 121 drilling sites along Nine yeast Ridge and dredges from the Broken Ridge (solid square) and the average of escolar CPUEs in Eastern Indian Ocean.

Source:(Duncan, 1991)

\section{CONCLUSION}

The majority of LEC in Eastern Indian Ocean was caught in mature condition with the average length $83.95 \mathrm{cmFL}$. Length-weight relationship of LEC was negative allometric that means the growth in length is faster than the growth in weight. This study suggests that the best area to catch LEC would be in coordinate $10-35^{\circ} \mathrm{S}$ and $85-110^{\circ} \mathrm{E}$ (Highest CPUE) with the best time to catch in June-August.

\section{ACKNOWLEDGEMENTS}

The authors thank to observers of Research Institute for Tuna Fisheries (RITF) Benoa Bali, Mr Abram Barata, Mr Andi Bachtiar, Mr Yusuf Affandi, Mr. Dian Novianto, Mr. Fathur Rochman, Mr Irwan Jatmiko, Mr. Ashadi, Mr. Hasan Syaiful Rizal, Mr. Adi Subagio for their assistence. We also deliver our gratitude to the Head of RITF, Budi Nugraha S.Pi, M.Si. for support and evaluable inputs. 


\section{REFERENCE}

Brendtro, K. S., McDowell, J. R., \& Graves, J. E. (2008). Population genetic structure of Escolar (Lepidocibium flavobrunneum). Marine Biology. 155.11-22 pp.

Collette, B. B., \& Nauen, C. E. (1983). FAO Species Catalogue. Scombrid of the world. FAO, Rome.

De Metrio, G., \& Megalofonou, P. (1998). Catch and Size Distribution, Growth and Sex Ratio of Swordfish (Xiphias gladius L.) in Gulf of Taranto. FAO Fisheries Report No. 394.

Duncan, R. A. (1991). Age Distribution of Volcanism Along a Seismic Ridges in the Eastern Indian Ocean. Proceeding of the Ocean Drilling Program.Scientific Result. 121. p. 507-517.

Feldman, K. A., Werner, S. B., Cronan, S., Hernandes, M., Horvath, A. R., Lea, C. S., Au, A. M., \& Vugia, D. J. (2005). A Large Outbreak of Scombroid Fish Poisoning Aassociated with Eating Escolar Fish (Lepidocybium flavobrunneum). Epidemiology and Infection Vol. 133/ issue 01/February 2005.p 2933.

Graves, J.E. (1998). Molecular Insights into the Population Structures of Cosmopolitan Marine Fish. J. Hered. 89, p. 427-437.

Gunarso, W., \& Wiyono, E.S. (1994). The Study on influence of season and catch technology to the catch of mackerel (Decapterus sp) in Java Sea. Bulletin of ITK Marite. Vol.4.No.1. Fisheries Faculty.Bogor Agriculture Institute. Bogor. p. 5558.

Keller, H. R., \& Kerstetter, D. W. (2012). Lengthlength and Length -weight Relationship of Oilfish (Ruvettus prettiosus), Escolar (Lepidocybium flavobrunneum), Snake Mackerel (Gempylus serpent) and Long Nose Lancetfish (Alepisaurus ferox) from the Gulf of Mexico and Western North Atlantic Ocean . Journal of Applied Ichthyology. 30(1), 241-243.

Levesque, J.C. (2010). Evolving Fisheries: Today's by Catch is Tomorrow Target Catch-Escolar (Lepidocybium flavobrunneum) Catch in the U.S Pelagic Longline Fishery. The Open Fish Science Journal, 2010, 3, p.30-41.
Lorenzo, J. M., \& Pajuelo, J. G. (1995). Population Biology of Roudi Escolar (Promethicthys Prometheus) (Gempylidae) of the Canary Island. Scientia Marina. 59 (3-4), 235-240.

Lorenzo, M. J., \& Pajuelo, J.G. (1999). Biology of Deep Benthopelagic Fish, Roudi Escolar Promethichthys prometheus (Gemplylidae), off the Canary Islands. Fish. Bull. 97, p. 92-99.

Nakamura, I., \& Parin, N.V. (1993). FAO Species Catalogue.Vol. 15. Snake Mackerels and Cutlass Fishes of the World (Families Gempylidae and Trichiuridae). An Annotated and Illustrated Catalogue of the Snake Mackerels, Snoeks, Escolars, Gemfishes, Sackfishes, Domine, Oilfish, Cutlassfishes, Scabbardfishes, Hairtails, and Frostfishes Known to Date. FAO Fish. Synop. 125(15),136 p.

Nishikawa, Y. (1982). Early Development of the Family Gempylidae. Larva and Juvenile of Escolar Lepidocybium flavobrunneum (Smith). Bull. Far Seas Fish. Res. Lab., No. 19. Nov. 1982. p 1-14.

Nishikawa, Y., \& Warashima, I. (1998). Escolar Lepidocybium flavobrunneum (Smith) Commercially Fish in Water Adjacent to the Pacific Coast of Japan. Bull. Far. Seas Fish Res. Laborat 1998. 25, 145-162.

Riede, K. (2004). Global Register of Migratory Species-from Global to Regional Scales. Final Report of the R\&D-Projekt 80805081 . Federal Agency for Nature Conservation, Bonn, Germany. $329 \mathrm{p}$.

Roche, P., Kirk, M., \& Bolt, S. (2002). Diarrhoea Associated with Consumption of Escolar (Rudderfish). Communicable Disease. Intelligence Quarterly Report. 26(3), 436-438.

Rogers, A.D. (2012). An Ecosystem Approach to Management of Seamounts in the Southern Indian Ocean. Volume 1 - Overview of Seamount Ecosystems and Biodiversity. Gland, Switzerland: IUCN. 18+iipp.

Sainsbury, K.J., Kailola, P.J., \& Leyland, G.G. (1985). Continental Shelf Fishes of Northern and NorthWestern Australia: An illustrated Guide. Canberra: Clouston \& Hall. 357 p. 
Shcherbachev, Y.N. (1987). Preliminary List of Thalassobathyal Fishes of the Tropical and Subtropical Waters of the Indian Ocean. J. Ichthyol. 27(2), 37-46.
Sommer, C., Schneider, W. \& Poutiers, J.M. (1996). FAO Species Identification Field Guide for Fishery Purposes. The Living Marine Resources of Somalia. $F A O$, Rome, $376 \mathrm{p}$. 